\title{
Pengaruh Religiusitas, Motivasi, Pengetahuan dan Pemahaman Perpajakan terhadap Perilaku Kepatuhan Wajib Pajak Orang Pribadi (Studi Empiris pada KPP Pratama Surabaya Genteng)
}

\author{
*Cynthia Dwi Arini, Arif Rahman, Mahsina \\ Prodi Manajemen Fakultas Ekonomi dan Bisnis \\ Universitas Bhayangkara Surabaya, Indonesia
}

DOI: $10.46821 /$ ekobis.v2i1.208

\begin{abstract}
ABSTRAK
Penelitian ini bertujuan untuk mengetahui pengaruh religiusitas, motivasi, pengetahuan dan pemahaman perpajakan terhadap perilkau kepatuhan wajib pajak orang pribadi. Jenis penelitian yang digunakan dalam penelitian ini adalah penelitian penjelasan (explanatory research) dengan metode penelitian kuantitatif. Populasi dalam penelitian ini adalah Wajib Pajak Orang Pribadi di KPP Surabaya Genteng. Sampel dalam penelitian ini berjumlah 99 responden dengan pendekatan insidental sampling. Instrumen penelitian ini menggunakan kuisioner dan diuji dengan validitas, reabilitas, analisis regresi berganda, koefisien determinasi dan uji hipotesis (uji t) dengan menggunkaan aplikasi SPSS. Hasil penelitian ini menunjukkan bahwa religiusitas, motivasi, pengetahuan dan pemahaman perpajakan yang dimiliki wajib pajak berpengaruh dan signifikan terhadap perilaku kepatuhan wajib pajak orang pribadi.
\end{abstract}

Kata Kunci: Religiusitas, Motivasi, Pengetahuan dan Pemahaman Perpajakan, Kepatuhan Pajak

\begin{abstract}
This study aims to determinate the effect of religiosity, motivation, knowledge and understanding on taxpayer compliance behavior of personal persons. The type of research used ini this research is explanatory research with quantitative research methods. The population of this study is the individual taxpayer at KPP Surabaya Genteng. The sample of this study amounted to 99 respondents with insidental sampling approach. The research instrument uses a questionnaire and tested with validity, reability, multiple regression analysis. coefficient of determination, and hypothesis testing ( $\mathrm{t}$ test) using the SPSS aplication. The results of this study inidicate that the taxpayer's religiosity, motivation, knowledge and understanding of taxation have an effect and sifnificant on the compliance behavior of individual taxpayer.
\end{abstract}

Keywords: Religiosity, Motivation, Knowledge and Understanding Taxation, Tax Compliance

\section{PENDAHULUAN}

Menurut Undang-undang KUP Nomor 28 Tahun 2007 Pasal 1 Ayat 1, "pajak adalah kontribusi wajib kepada negara terutang oleh orang pribadi atau badan yang bersifat memaksa berdasarkan Undang-undang, dengan tidak mendapat timbal balik secara langsung dan digunakan untuk keperluan negara bagi sebesar- 
besarnya kemakmuran rakyat". Pajak sebagai salah satu aspek penyumbang kas negara memberikan manfaat yang sangat besar bagi kehidupan masyarakat seharihari. Peningkatan pemasukan pajak dalam negara berimbas pada pembangunan infrastruktur dan pemerataan perekonomian negara. Begitu pentingnya peran pajak, hal ini dapat dilihat dari APBN (Anggaran Pendapatan dan Belanja Negara) 2020. Berikut APBN tahun lima tahun terakhir.

Tabel 1 membuktikan bahwa pajak menyumbang lebih dari $75 \%$ dalam pendapatan negara. Semakin besar pajak yang dipungut negara semakin besar pula manfaat yang diperoleh dalam menikmati sarana dan prasarana yang disediakan oleh negara baik pemerintah pusat maupun pemerintah daerah. Hal ini tentunya sangat dipengaruhi oleh kepatuhan wajib pajak dalam membayar pajak. Namun kepatuhan wajib pajak masih menjadi permasalahan di dunia termasuk Indonesia. Dikutip Iswan (2019), kepatuhan pajak berkaitan erat dengan tax ratio. Tax ratio atau rasio pendapatan pajak merupakan formula mengukur kinerja perpajakan dengan membandingkan penerimaan perpajakan dan Produk Domestik Bruto (PDB) dalam kurun waktu tertentu. Semakin rendah tax ratio, maka semakin rendah pula kepatuhan wajib pajak dalam negeri (Asmara, 2018). Bersumber dari World Development Indicator (2019), World Bank tingkat tax ratio Indonesia lebih rendah bila dibandingkan dengan negara-negara tetangga. Tax ratio Indonesia berada di angka 10,2\%, masih berada dibawah Filipina (14,0\%), Malaysia (12,0\%), dan Thailand (14,9\%).

Menurut Rahayu (2017) tidak semua wajib pajak melaksanakan kewajiban perpajakannya secara benar serta dilandasi oleh kesadaran dan itikad baik. Kepatuhan wajib pajak dalam melaksanakan kewajiban perpajakan dipengaruhi oleh sikap wajib pajak yang lain. Bila sebagian besar wajib melakukan pelanggaran pajak maka wajib pajak yang mengetahuinya akan mengambil kecenderungan melanggar, demikian juga sebaliknya. Pada kenyataannya masih banyak wajib pajak yang berperilaku tidak patuh (Mubarokah dkk, 2020). Perilaku yang terkait antara lain adalah tidak menyampaikan surat pemberitahuan tahunan, tidak melaporkan biaya sesungguhnya, menghindari pengenaan pajak yang seharusnya dibayarkan, dan masih banyak lagi perilaku ketidakpatuhan yang lain.

Tabel 1

Pendapatan Negara Dalam Negeri (dalam triliun rupiah)

\begin{tabular}{ccccc}
\hline Tahun & $\begin{array}{c}\text { Penerimaan } \\
\text { Perpajakan }\end{array}$ & $\begin{array}{c}\text { Penerimaan Negara } \\
\text { Bukan Pajak }\end{array}$ & Total & $\begin{array}{c}\text { Persentase } \\
\text { Perpajakan }\end{array}$ \\
\hline 2016 & $1.285,0$ & 262,2 & $1.547,2$ & $83 \%$ \\
2017 & $1.343,5$ & 311,2 & $1.654,7$ & $81 \%$ \\
2018 & $1.518,8$ & 409,3 & $1.928,1$ & $78 \%$ \\
2019 & $1.643,1$ & 386,3 & $2.029,4$ & $80 \%$ \\
2020 & $1.865,7$ & 367,0 & $2.232,7$ & $83 \%$ \\
\hline
\end{tabular}

Sumber : kemenkeu.go.id, APBN 
Bangsa Indonesia termasuk negara yang sangat memegang teguh nilainilai keagamaan, hal ini tercermin dari sila pertama Pancasila sebagai ideologi Indonesia. Nilai-nilai keagamaan atau religiusitas didalam diri seseorang diharapkan memberikan sugesti untuk selalu melakukan perbuatan sesuai perintah dan menjauhi larangan sesuai agama yang dianutnya. Menurut Ermawati (2018), wajib pajak yang religius dapat dilihat dari sikapnya dalam mematuhi peraturan perpajakannya. Wajib pajak yang taat akan agama yang dianut akan mematuhi peraturan perpajakannya karena takut melanggar agama yang akan berakibat dosa.

Kepatuhan wajib pajak dalam ketepatan pelaporan SPT didukung oleh motivasi pribadi untuk melaksanakan kewajibannya terhadap negara. Motivasi membayar pajak adalah kekuatan potensial yang ada dalam diri wajib pajak yang melatar belakangi seorang wajib pajak untuk membayar pajak. Motivasi ini bisa timbul dari dalam maupun luar individu. Persepsi masyarakat mengenai pajak sangat erat kaitannya dengan kesadaran masyarakat sebagai wajib pajak. Perilaku kepatuhan seseorang di pengaruhi oleh motivasi yang mendasari dalam diri wajib pajak.

Ketidaktahuan seseorang mengenai perpajakan akan mengakibatkan seseorang bertindak masa bodoh dan tidak mau peduli akan kewajiban perpajakan yang harusnya dilakukan. Kurang tertariknya masyarakat dalam membayar pajak dikarenakan karena tidak adanya timbal balik secara langsung yang dirasakan masyarakat terhadap pajak yang dibayarkan kepada negara. Semakin tinggi tingkat pengetahuan dan pemahaman wajib pajak, maka semakin mudah pula bagi mereka untuk memahami peraturan perpajakan dan semakin mudah pula utuk memenuhi kewajiban perpajakannya (Nurmuntu, 2005:32).

Berdasarkan latar belakang yang sudah diuraikan, penulis tertarik untuk melakukan penelitian dengan objek orang pribadi yang termasuk wajib pajak. Maka untuk penelitian ini diambil judul "Pengaruh Religiusitas, Motivasi, Pengetahuan dan Pemahaman Perpajakan Terhadap Perilaku Kepatuhan Wajib Pajak Orang Pribadi (Studi Empiris pada Kantor Pelayanan Pajak Pratama Surabaya Genteng)”.

\section{TINJAUAN PUSTAKA}

\section{Kepatuhan Wajib Pajak}

Kepatuhan wajib pajak dapat didefinisikan sebagai suatu keadaan dimana wajib pajak memenuhi semua kewajiban perpajakan dan melaksanakan hak perpajakannya (Nurmantu, 2005:148). Menurut Nurmantu, terdapat dua macam kepatuhan, yaitu kepatuhan formal dan kepatuhan material. Kepatuhan formal adalah suatu keadaan dimana wajib pajak memenuhi kewajiban perpajakan secara formal sesuai dengan ketentuan dalam undang-undang perpajakannya. Kepatuhan material adalah keadan dimana wajib pajak secara substantif/hakekat memenuhi semua ketentuan material perpajakan, yakni sesuai isi dan jiwa undang-undang perpajakan.

\section{Religiusitas}

Religiusitas menjadi sumber dari segala sesuatu yang menjadi tolak ukur individu berpedoman dalam menjalankan aktivitas ibadah atas agama yang dianutnya. Definisi religius menurut Glock dan Stark (dalam Ancok \& Suroso, 2001) merupakan seberapa jauh pengetahuan, seberapa kokoh keyakinan, dan 
seberapa tekun pelaksanaan ibadah dan seberapa dalam penghayatan agama yang dianut seseorang. Menurut Glock (1962) dalam Basri (2014) religiusitas dapat dibagi menjadi lima dimensi, yaitu dimensi ideologis, dimensi ritualistik - praktek keagamaan, dimensi pengalaman, imensi intelektual, dan dimensi konsekuensial.

\section{Motivasi}

Menurut Wursanto (2004) mengatakan definisi motivasi adalah alasan-alasan, dorongan-dorongan yang ada di dalam diri individu yang menyebabkan seseorang melakukan sesuatu atau perbuatan sesuatu. Menurut Luthans (1985) siklus motivasi terdiri dari tiga elemen, yaitu adanya kebutuhan (needs), dorongan berbuat dan bertindak (drives), dan tujuan yang diinginkan (goals). Menurut Widyatun (1999) bentuk motivasi individu ada 3, yaitu motivasi intrinsik, motivasi ekstrinsik, dan motivasi terdesak. Sulistiyono dalam Prabu (2005) menyatakan motivasi seseorang dipengaruhi oleh beberapa faktor, dintaranya adalah tingkat kematanagn pribadi, situasi dan kondisi, lingkungan kerja atau aktifitas, tingkat pendidikan mempengaruhi pengetahuan seseorang, audio visual (media), serta sarana dan prasarana.

\section{Pengetahuan dan Pemahaman Perpajakan}

Menurut Ermawati (dalam Ilhamsyah dkk, 2015), pengetahuan perpajakan adalah ilmu yang dimiliki wajib pajak yang mencakup : hak dan kewajiban wajib pajak, paham mengenai NPWP, sanksi perpajakan, tarif pajak, PTKP (Penghasilan Tidak Kena Pajak), proses membayar dan melaporkan pajak. Pengetahuan perpajakan merupakan seberapa besar ilmu yang dimiliki wajib pajak mengenai manfaat pajak yang telah disetorkan ke kas negara (Ermawati dalam Febriani, 2015). Pemahaman terhadap peraturan perpajakan adalah cara wajib pajak dalam memahami peraturan perpajakan yang telah ada (Susherdiyanto dalam Hardiningsih, 2011). Kurang pahamnya wajib pajak mengenai peraturan perpajakan menyebabkan wajib pajak cenderung tidak patuh dalam membayar pajak, dan sebaliknya wajib pajak yang paham akan cenderung patuh dalam membayar pajak.

\section{Teori Atribusi Penelitian}

Teori atribusi pertama kali diperkenalkan oleh Fritz Heider pada tahun 1958 kemudian dikembangkan lagi oleh Harold Kelley (1972). Teori atribusi menyatakan bahwa dalam mengamati perilaku orang lain, individu tersebut akan mencoba untuk memahami apakah perilaku tersebut ditimbulkan secara internal atau eksternal (Myers, 1996). Menurut Robbins dan Judge (2008), penentuan apakah perilaku disebabkan secara internal atau eksternal dipengaruhi tiga faktor, yaitu kekhususan, konsensus, dan konsistensi. Menurut Julianti (2014) adanya relevansi teori atribusi terhadap kepatuhan wajib pajak adalah seseorang dalam berperilaku patuh atau tidak patuh untuk memenuhi kewajiban perpajakannya dipengaruhi oleh faktor internal maupun faktor eksternal. Faktor internal yang dapat yang dimaksud antara lain kesadaran wajib pajak, kondisi keuangan wajib pajak, pengetahuan dan pemahaman wajib pajak mengenai perpajakan. Faktor eksternal yang dapat memengaruhi antara lain kualitas pelayanan, sistem perpajakan, sanksi perpajakan, dan tarif perpajakan. 


\section{Theory of Planned Behaviour (TPB)}

Theory Planned Behaviour (TPB) pertama kali dikemukakan oleh Ajzen (1991). Dimana teori tersebut menjelaskan bahwa perilaku yang ditimbulkan oleh individu muncul karena faktor-faktor yang mempengaruhi niat seseorang untuk berperilaku dilihat dari sisi psikologis. Niat itu sendiri disebabkan oleh tiga faktor, yaitu behavioral belief, normative beliefs, dan control belifs. Teori ini dianggap relevan dan dapat memperkuat teori atribusi yang sudah dibahas sebelumnya. Asumsi yang terbentuk dalam pemikiran individu akan mempengaruhi niat seseorang sebelum melakukan sesuatu. Hasil evaluasi yang diperoleh kemudian berdampak pada sikap individu apakah dia akan memenuhi kewajiban perpajakannya atau tidak.

\section{Teori Pembelajaran Sosial}

Teori pembelajaran sosial diperkenakan oleh Bandura (1977). Teori ini menyatakan bahwa seseorang dapat belajar bahwa lewat pengamatan dan pengalaman langsung (Robbins dan Judge, 2008). Terdapat empat proses dalam pembelajaran sosial, yaitu proses perhatian (attentional), proses penahanan (retention), proses reproduksi motorik, proses penegasan (reinforcement). Jatmiko (2006) menyatakan teori ini relevan untuk menjelaskan perilaku wajib pajak dalam memenuhi kewajiban perpajakannya. Teori ini menjelaskan wajib pajak akan patuh memenuhi kewajibannya apabila mereka mengamati dan mempunyai pengalaman secara langsung bahwa pajak yang telah dibayarkan dipergunakan untuk membangun wilayahnya. Terkait dengan proses perhatian, seseorang akan taat terhadap kewajiban pajak apabila seseorang tersebut mengenal dan menaruh perhatian terhadap peraturan serta undang-undang dan tata cara perpajakan. Seseorang akan memiliki kesadaran dalam memahami dan mematuhi peraturan perpajakan sebagai proses penahanan dalam teori pembelajaran sosial (Amin, 2018).

\section{Hipotesis Penelitian}

H1 : Religiusitas berpengaruh terhadap kepatuhan wajib pajak orang pribadi.

$\mathrm{H} 2$ : Motivasi berpengaruh terhadap kepatuhan wajib pajak orang pribadi.

H3 : Pengetahuan dan pemahaman perpajakan berpengaruh terhadap kepatuhan wajib pajak orang pribadi.

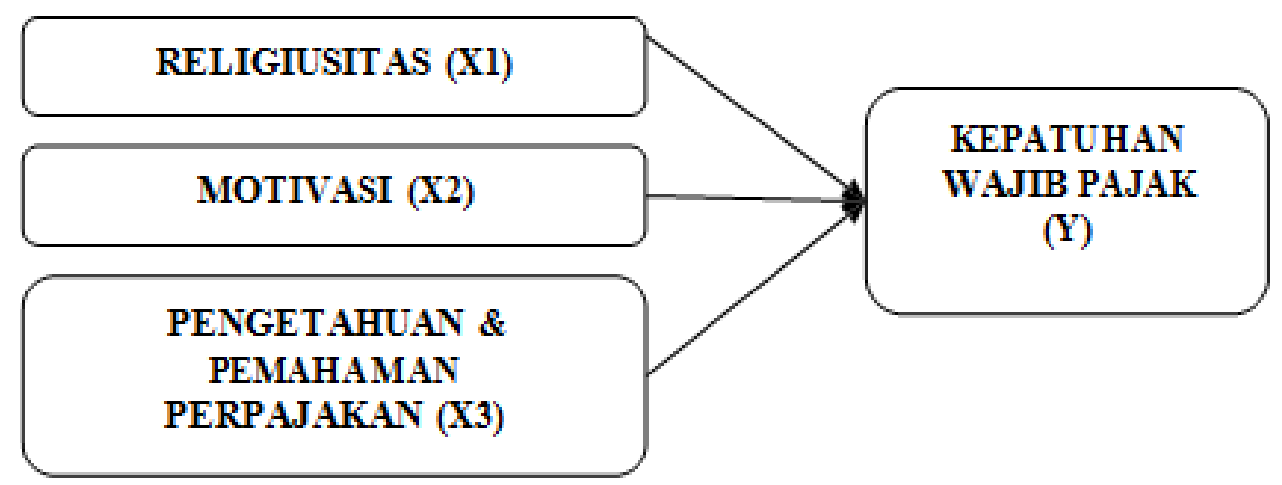

Gambar 1. Kerangka Konseptual 


\section{METODE PENELITIAN}

\section{Jenis Penelitian}

Jenis penelitian yang digunakan dalam penelitian ini adalah penelitian penjelasan (explanatory research) dengan metode penelitian kuantitatif dan dilakukan pada Kantor Pelayanan Pajak Pratama Surabaya Genteng. Lokasi perusahaan ini terletak di Jalan Kayoon No. 28, Embong Kaliasin, Kecamatan Genteng, Kota Surabaya.

\section{Metode Pengumpulan Data}

Teknik pengumpulan data dalam penelitian ini adalah menggunakan kuesioner. Jenis yang digunakan adalah kuesioner tertutup dengan memberikan secara langsung dan kuesioner dijawab oleh responden yang bersangkutan. Kuesioner ini terbagi atas dua bagian yaitu, bagian pertama yang berisi pernyataan mengenai responden, dan bagian kedua mengenai pertanyaan tentang variabel independen dan variabel dependen.

\section{Populasi dan Sampel}

Populasi dalam penelitian ini adalah wajib pajak orang pribadi yang terdaftar di Kantor Pajak Pratama (KPP) Surabaya Genteng sebanyak 11.960 orang. Penulis menggunakan sampel sebanyak 99 responden. Teknik pengambilan sampel yang digunakan penulis adalah insidental sampling. Teknik ini merupakan salah satu teknik non probability sampling dimana teknik penentuan sampel berdasarkan kebetulan, yaitu siapa saja yang secara kebetulan/insidental bertemu dengan peneliti dapat digunakan sampel, bila dipandang orang yang kebetulan ditemui itu cocok sebagai sumber data (Sugiyono, 2009:85).

\section{Metode Analisis}

Dalam penelitian akan dianalisis dengan menggunakan SPSS 19.0 dan analisis statistik yang meliputi analisis deskriptif, uji kualitas (uji validitas dan reliabilitas), analisis regresi berganda, koefisien determinasi dan uji hipotesis (uji Statistik T).

\section{HASIL ANALISIS DAN PEMBAHASAN Uji Statistik Deskriptif}

Data penelitian diperoleh dari hasil kuesioner yang telah disebarkan kepada responden penelitian sejumlah 99 orang wajib pajak orang pribadi yang terdaftar di Kantor Pelayanan Pajak Pratama Surabaya Gubeng. Karakteristik responden meliputi jenis kelamin, umur, dan pekerjaan responden. Informasi mengenai karakteristik variabel penelitian, antara lain nilai minimum, maksimum,mean (rata-rata) dan standar deviasi disajikan dengan menggunakan statistik deskriptif.

\section{Tabel 2}

Hasil Uji Statistik Desktiptif Descriptive Statistics

\begin{tabular}{lrrlll}
\hline & Minimum & Maximum & Mean & Std. Deviation & N \\
\hline $\mathrm{Y}$ & 35 & 50 & 44.82 & 3.400 & 99 \\
$\mathrm{X} 1$ & 19 & 30 & 26.86 & 2.095 & 99 \\
$\mathrm{X} 2$ & 38 & 55 & 48.89 & 3.617 & 99 \\
$\mathrm{X} 3$ & 25 & 40 & 35.49 & 2.585 & 99
\end{tabular}

Sumber: Data Diolah (2021) 
Berdasarkan Tabel 2 menunjukkan statistik deskriptif dari variabel-variabel yang diteliti, Variabel kepatuhan pajak memiliki nilai minimum sebesar 35 dan nilai maksimum sebesar 40. Nilai rata-rata untuk variabel sanksi perpajakan adalah sebesar 44,82 dengan penyimpangan sebesar 3,400. Berdasarkan data tersebut, sebaran data penelitian merata. Variabel religiusitas memiliki nilai minimum sebesar 19 dan nilai maksimum sebesar 50. Nilai rata-rata untuk variabel religiusitas adalah sebesar 26,86 dengan penyimpangan sebesar 2,095. Berdasarkan data tersebut sebaran data kesadaran wajib pajak cukup merata. Variabel motivasi perpajakan memiliki nilai minimum sebesar 38 dan nilai maksimum sebesar 55. Nilai rata-rata untuk variabel motivasi adalah sebesar 48,89 dengan penyimpangan sebesar 3,617. Data penelitian memiliki sebaran data yang merata. Variabel pengetahuan dan pemahaman perpajakan memiliki nilai minimum sebesar 25 dan nilai maksimum sebesar 40. Nilai rata-rata untuk variabel kualitas pelayanan adalah sebesar 35,49 dengan penyimpangan sebesar 2,585. Sebaran data penelitian ini merata.

\section{Uji Validitas}

Valid berarti instrumen penelitian tersebut dapat digunakan untuk mengukur apa yang hendak diukur. Suatu alat ukur disebut valid jika instrumen yang dimaksud untuk mengukur tersebut memang dapat mengukur apa yang seharusnya diukur secara tepat (Putri dalam Sugiyono, 2005:267). Dengan pedoman bila r-hitung > r-tabel pada signifikansi 5\% maka butir dianggap valid, sedangkan bila $\mathrm{r}$--hitung $<\mathrm{r}$ tabel maka item tersebut dianggap tidak valid. Untuk pengujian validitas menggunakan metode koefisien korelasi Product Moment dengan jumlah sampel sebanyak 99. Maka nilai $\mathrm{r}$ - tabel di dapat dari $\mathrm{df}=\mathrm{N}-2$ dengan pengujian 2 arah pada tingkat signifikansi 0.05 yaitu sebesar 0.1975 .

\section{Uji Reabilitas}

Untuk menguji keandalan (reliabel) suatu pernyataan digunakan teknik analisis Cronbach's Alpha untuk tiap variabel penelitian. Hasil pengujian ini dapat dikatakan reliabel apabila Cronbach's Alpha > 0,6 (Malhotra, 2012:289). Hasil uji reliabilitas dari variabel-variabel yang diteliti dapat dilihat pada Tabel 3.

\section{Analisis Regresi Linear Berganda}

Analisis regresi digunakan untuk mengetahui sejauh mana hubungan antara variabel bebas terhadap variabel terikat. Berdasarkan analisis regresi dengan menggunakan SPSS diperoleh hasil yang terdapat pada Tabel 4.

\section{Tabel 3}

Hasil Uji Reliabilitas

\begin{tabular}{lclc}
\hline \multicolumn{1}{c}{ Variabel } & Cronbach's Alpha & Kriteria & Keterangan \\
\hline Religiusitas $\left(\mathrm{X}_{1}\right)$ & 0,734 & 0.6 & Reliabel \\
Motivasi $\left(\mathrm{X}_{2}\right)$ & 0,846 & 0.6 & Reliabel \\
Pengetahuan \& Pemahaman & 0,778 & 0.6 & Reliabel \\
Perpajakan (X3) & & & \\
Kepatuhan Wajib Pajak (Y) & 0,845 & 0.6 & Reliabel
\end{tabular}

Sumber: Data Primer Diolah dengan SPSS (2021) 


\section{Tabel 4}

\section{Regresi Linier Berganda}

\begin{tabular}{|c|c|c|c|c|c|c|c|}
\hline \multirow{2}{*}{\multicolumn{2}{|c|}{ Model }} & \multicolumn{2}{|c|}{ Unstandardized Coefficients } & \multicolumn{2}{|c|}{ Standardized } & \multirow[b]{2}{*}{$\mathrm{t}$} & \multirow[b]{2}{*}{ Sig. } \\
\hline & & B & Std. Error & Beta & & & \\
\hline 1 & (Constant) & -2.014 & 2.011 & & & -1.002 & .319 \\
\hline & $\mathrm{X} 1$ & .452 & .093 & & .279 & 4.846 & .000 \\
\hline & $\mathrm{X} 2$ & .505 & .055 & & .537 & 9.142 & .000 \\
\hline & X3 & .282 & .080 & & .214 & 3.532 & .001 \\
\hline
\end{tabular}

Sumber: Data Primer Diolah dengan SPSS (2021)

Berdasarkan Tabel 4, maka persamaan regresi yang terbentuk adalah sebagai berikut:

$$
\begin{aligned}
& Y=\alpha+\beta 1 X 1+\beta 2 X 2+\beta 3 X 3+e \\
& Y=-2.014+0.452 X 1+0.505 X 2+0.282 X 3+e
\end{aligned}
$$

Keterangan:

$$
\begin{array}{ll}
\mathrm{Y} & : \text { Kepatuhan wajib pajak } \\
\alpha & : \text { Konstanta } \\
\beta 1, \beta 2, \beta 3 & : \text { Koefisien Regresi } \\
\mathrm{X} 1 & \text { : Religiusitas } \\
\mathrm{X} 2 & : \text { Motivasi } \\
\mathrm{X} 3 & : \text { Pengetahuan \& pemahaman perpajakan } \\
\mathrm{e} & : \text { Residual Error dari masing-masing variable }
\end{array}
$$

\section{Koefisien Determinasi}

Pengukuran koefisien determinasi berganda bertujuan untuk mengetahui besarnya korelasi dan hubungan variabel dari model regresi pada penelitian ini serta mengukur seberapa dekat garis regresi yang diestimasi terhadap data yang sebenarnya. Hasil pengukuran koefisien korelasi berganda penelitian ini dapat dilihat pada Tabel 5.

Dari Tabel 5 menjelaskan bahwa hasil menujukkan $\mathrm{R}$ sebesar 0.924 menunjukkan bahwa hubungan korelasi antara variable $\mathrm{Y}$ dengan variabel $\mathrm{X} 1$, $\mathrm{X} 2, \mathrm{X} 3$ adalah kuat, karena nilai $\mathrm{R}$ lebih dari 0.5 maka dapat dikatakan berkorelasi kuat. nilai koefisien determinasi berganda adjusted $R$ Square adalah 0.850 atau sebesar $85 \%$. Nilai ini menujukkan variasi variabel kepatuhan wajib pajak dipengaruhi oleh variabel religuisitas (X1), motivasi (X2), pengetahuan \& pemahaman perpajakan (X3) sisanya sebesar $15 \%$ berhubungan dengan variabel lain.

\section{Tabel 5}

\section{Hasil Perhitungan Uji Koefisiensi $\mathbf{R}$ dan $\mathbf{R}_{\mathbf{2}}$}

\begin{tabular}{lrrrrr}
\hline Model & R & R Square & Adjusted R Square & \multicolumn{2}{c}{ Std. Error of the Estimate } \\
\hline 1 & $.924 \mathrm{a}$ & .854 & .850 & 1.319 \\
\hline
\end{tabular}

Sumber: Data Primer Diolah dengan SPSS (2021) 
Tabel 6

Uji t (Parsial)

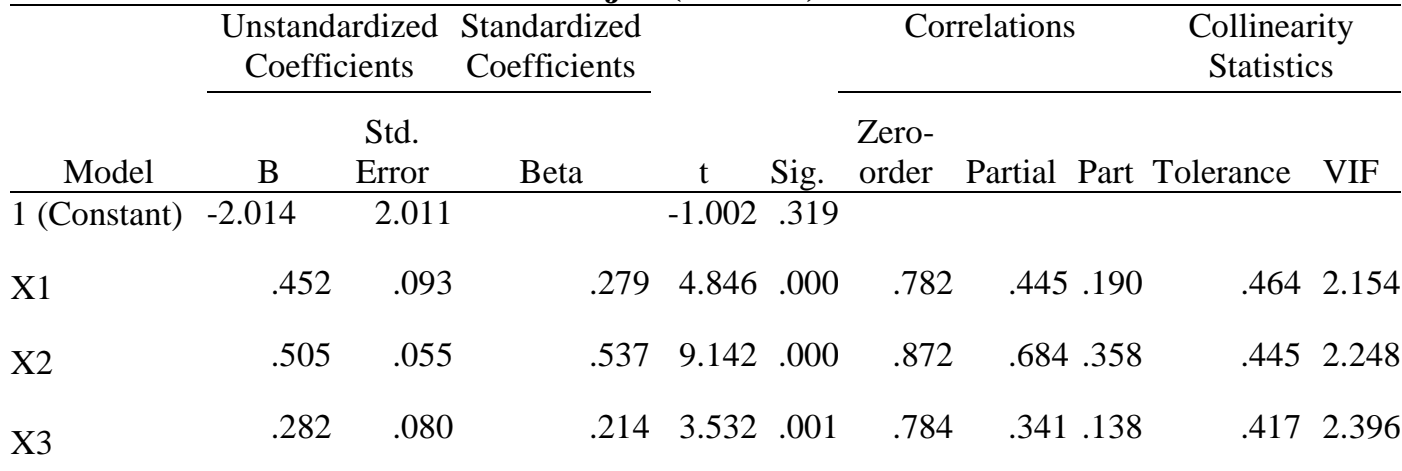

a. Dependent Variable: $\mathrm{Y}$

Sumber: Data Primer Diolah dengan SPSS (2021)

\section{Uji Parsial (Uji t)}

Uji statistik t pada dasarnya menunjukkan seberapa jauh pengaruh satu variabel penjelas atau independen secara individual dalam menerangkan variasi variabel dependen (Ghozali, 2006). Uji t bertujuan mengidentifikasi apakah variabel independen secara parsial berpengaruh signifikan terhadap variabel dependen. Uji $t$ dalam penelitian ini menggunakan taraf signifikasi $5 \%$ atau 0,05 dengan pengujian dua sisi dan df $(\mathrm{n}-\mathrm{k})$ maka diperoleh $\mathrm{t}$ tabel $=1,985$. Diketahui $\mathrm{t}$-tabel $=$ 1,985. Dari Tabel 6 dapat dijelaksan sebagai berikut :

a. (X1) : t-hitung $(4,846)>$ t-tabel $(1,985)$, signifikansi $0,000<0,05=\mathrm{H} 1$ diterima $\mathrm{H0}$ ditolak, signifikan.

b. (X2) : t-hitung $(9.142)>\mathrm{t}$-tabel $(1,985)$, signifikansi $0,000<0,05=\mathrm{H} 1$ diterima $\mathrm{H} 0$ ditolak, signifikan.

c. (X1) : t-hitung $(3,532)>$ t-tabel $(1,985)$, signifikansi $0,001<0,05=\mathrm{H} 1$ diterima $\mathrm{H} 0$ ditolak,signifikan.

\section{Pengaruh Religiusitas terhadap Kepatuhan Wajib Pajak}

Berdasarkan hasil analisis regresi berganda yang telah didapatkan, maka diperoleh nilai koefisien regresi berganda yang bernilai positif yaitu sebesar 0.452 , serta t-hitung lebih besar daripada t-tabel $(4.846>1.985)$ pada tingkat signifikansi 5\%. Nilai signifikansi variabel religiusitas terhadap kepatuhan wajib pajak orang pribadi menunjukkan angka yang lebih kecil jika dibandingkan nilai signifikansi $\alpha=5 \%(0,000<0,05)$. Dengan demikian, maka dapat diartikan bahwa religiusitas berpengaruh dan signifikan terhadap kepatuhan wajib pajak orang pribadi. Hasil dari penelitian ini mendukung Teori Atribusi yang menjelaskan dalam mengamati perilaku orang lain, individu tersebut akan mencoba untuk memahami apakah perilaku tersebut ditimbulkan secara internal ataupun eksternal (Myers, 1996). Apabila dikaitkan dengan teori ini, maka religiusitas termasuk kedalam faktor internal yaitu dispotional atributions (penyebab internal) yang mengacu perilaku individu dalam hal ini seperti kepribadian, persepsi diri, kemampuan dan motivasi. Dengan adanya nilai-nilai agama yang dipegang oleh individu diharapkan memicu sikap positif dan mencegah sikap negatif dalam kehidupan sehari-hari. 


\section{Pengaruh Motivasi terhadap Kepatuhan Wajib Pajak}

Hasil penelitian menunjukkan bahwa motivasi berpengaruh dan signifikan terhadap kepatuhan wajib pajak orang pribadi di KPP Pratama Surabaya Genteng. Hal tersebut dapat dilihat dari nilai koefisien regresi berganda yang bernilai positif yaitu sebesar 0.505, serta t-hitung lebih besar daripada t-tabel $(9.142>1.985)$ pada tingkat signifikansi 5\%. Selain itu, nilai signifikansi variabel motivasi terhadap kepatuhan wajib pajak orang pribadi lebih kecil jika dibandingkan nilai signifikansi $\alpha=5 \%(0,000<0,05)$ yang menunjukkan variabel motivasi berpengaruh secara signifikan terhadap kepatuhan wajib pajak orang pribadi. Seperti yang telah diketahui bahwa motivasi merupakan faktor yang berasal dari setiap individu. Semakin tinggi motivasi seorang wajib pajak dalam membayar pajak, maka semakin tinggi pula tingkat kepatuhannya. Hal tersebut dikarenakan mereka memiliki pemikiran yang positif dalam hal membayar pajak. Mereka menyadari membayar pajak merupakan salah satu kewajiban warga negara agar pembangunan negara dapat berjalan dengan baik.

\section{Pengaruh Pengetahuan dan Pemahaman Perpajakan terhadap Kepatuhan Wajib Pajak}

Berdasarkan hasil analisis regresi berganda yang telah dilakukan diperoleh bahwa variabel bebas pengetahuan dan pemahaman perpajakan terhadap kepatuhan wajib pajak memiliki nilai t-hitung lebih besar dari t-tabel (3,532 > 1,985). tingkat signifikansi sebesar $0,001<0,05$ dan memiliki koefisien yang berpengaruh positif sebesar 0,282. Artinya variabel pengetahuan dan pemahaman perpajakan berpengaruh signifikan terhadap kepatuhan wajib pajak. Pengetahuan dan pemahanan memiliki pengaruh terhadap tingkat kepatuhan. Hal ini dikarenakan semakin tinggi pengetahuan dan pemahaman perpajakan yang dimiliki wajib pajak, maka semakin besar kemungkinan wajib pajak tidak akan melanggar peraturan dan ketentuan perpajakan yang berlaku sehingga pengetahuan wajib pajak juga akan meningkat seiring dengan peraturan perpajakan yang terus berkembang. Sesuai dengan sistem pemungutan pajak Self Assessment System dimana wajib pajak menghitung, memotong, dan menyetorkan sendiri pajak yang ditanggungya, maka dalam hal ini wajib pajak diharuskan mengerti tata cara dan ketentuan perpjakan yang berlaku. Hal ini sesuai dengan Teori Pembelajaran Sosial dimana wajib pajak dapat mempelajari sistem perpajakan lewat pengamatan dan pengalaman langsung.

\section{SIMPULAN}

Berdasarkan hasil penelitan tersebut dapat disimpulkan dianataranya adalah: (1) Variabel religiusitas $(\mathrm{X} 1)$ memiliki nilai t-hitung > dari t-tabel $(4.846>1.985)$ dengan tingkat signifikansi sebesar $0.000<0.05$ dan koefisien sebesar 0,452 . Hal ini menunjukkan bahwa religiusitas berpengaruh dan signifikan terhadap kepatuhan wajib pajak (Y). (2) Variabel motivasi $(\mathrm{X} 2)$ memiliki nilai t-hitung $>$ dari t-tabel $(9.142>1.985)$ dengan tingkat signifikansi sebesar $0.000<0.05$ dan koefisien sebesar 0,505. Hal ini menunjukkan bahwa motivasi berpengaruh dan signifikan terhadap kepatuhan wajib pajak (Y). (3) Variabel pengetahuan dan pemahaman (X3) memiliki nilai t-hitung > dari t-tabel $(3,532>1.985)$ dengan tingkat signifikansi sebesar $0.001<0.05$ dan koefisien 
sebesar 0,282. Hal ini menunjukkan bahwa pengetahuan dan pemahaman berpengaruh positif dan signifikan terhadap kepatuhan wajib pajak (Y). Saran untuk pihak Kantor Pelayanan Pajak Pratama wajib mengetahui faktor-faktor yang mempengaruhi kepatuhan wajib pajak, serta sebaiknya terus melakukan sosialisasi terkait perpajakn terhadap wajib pajak guna meningkatkan pendapatan pajak, juga meningkatkan kepatuhan wajib pajak. Saran bagi peneliti yang akan melakukan penelitian selanjutnya, penelitian ini diharapkan dapat dimanfaatkan sebagai referensi, pendukung, pedoman, pembanding, dan diharapkan untuk menambah variabel lain yang dapat dijadikan indikator dalam penelitian lanjutan tentang faktor yang mempengaruhi kepatuhan wajib pajak.

\section{DAFTAR PUSTAKA}

Ancok, D. \& Suroso, N. (2001). Psikologi Islami: Solusi Islami Atas Problem-problem Psikologi. Yogyakarta: Pustaka Pelajar.

Ermawati, N. (2018). Pengaruh Religiusitas, Kesadaran Wajib Pajak dan Pengetahuan Perpajakan terhadap Kepatuhan Wajib Pajak. Jurnal STIE Semarang Vol 10 No. 1, 106-122.

Ermawati, N., \& Afifi, Z. (2018). Pengaruh Pengetahuan Perpajakan dan Sanksi Perpajakan terhadap Kepatuhan Wajib Pajak Dengan Religiusitas Sebagai Variabel Pemoderasi.

Mardiasmo. 2018. Perpajakan Edisi Terbaru 2018. Jakarta: Penerbit ANDI. Nurmantu, Safri. 2005. Pengantar Perpajakan, Jakarta: Yayasan Obor Indonesia. Purwadi, M. O. D., \& Setiawan, P. E.(2019). Pengaruh Religiusitas, Pelayanan Fiskus dan Sanksi Pajak pada Kepatuhan Wqajib Pajak Orang Pribadi. E-Jurnal Akuntansi, 28 (3), 2110-2125.

Putri, K. J., \& Setiawan, P. E. (2017). Pengaruh Kesadaran, Pengetahuan dan Pemahaman Perpajakan, kualitas pelayanan dan sanksi perpajakan terhadap kepatuhan Wajib Pajak. E-Jurnal Akuntansi, 18(2), 1112-1140.

Putri, Rolalita Lukmana, (2016) "Pengaruh Motivasi Membayar Pajak dan Tingkat Pendidikan terhadap Kepatuhan Wajib Pajak Orang Pribadi Pada Kantor Wilayah Direktorat Jenderal Pajak Daerah Istimewa Yogyakarta Tahun 2015”. Skripsi. Jurusan Akuntansi Fakultas Ekonomi Universitas Negeri, Yogyakarta.

Rajagukguk, M Sondang dan Fitri Sulistianti.2011. Religiousity Over Law And Tax Compliance. Diambil dari: Schoolar.google.com (5 Maret 2021).

Setiyani, N. M., Andini, R., \& Oemar, A. (2018). Pengaruh Motivasi Wajib Pajak dan Pengetahuan Perpajakan Terhadap Kepatuhan Wajib Pajak Orang Pribadi Dengan Kesadaran Wajib Pajak Sebagai Vaeiabel Intervening (Pada Kantor Pelayanan Pajak Pratama di Kota Semarang). Journal of Accounting, 4(4). 
Ekobis: Jurnal Ekonomi \& Bisnis

Vol. 2 No. 12021

Cynthia Dwi Arini dkk., Perilaku Kepatuhan Wajib Pajak

Sofha, D. (2018). Keterkaitan Religiusitas, Gender, Lom dan Persepsi Etika Penggelapan Pajak. Jurnal Ilmu Manajemen dan Akuntansi Terapan (JIMAT), 9 (2), 44-62.

Sugiyono. 2005. Statistika untuk Penelitian. Bandung: Alfabeta. Waluyo. 2012. Akuntansi Pajak Edisi Ketiga. Jakarta: Salemba Empat. 